\title{
Potential use of Pennisetum purpureum for phytoremediation and bioenergy production: a mini review
}

\author{
Nurul Atiqah Osman ${ }^{\mathrm{a}}$, Ahmad Muhaimin Roslan, ${ }^{\mathrm{a}, \mathrm{b}^{*}}$, Mohamad Faizal Ibrahimª, ${ }^{\mathrm{a}, \mathrm{b}}$, Mohd Ali Hassan ${ }^{\mathrm{a}}$ \\ ${ }^{a}$ Department of Bioprocess Technology, Faculty of Biotechnology and Biomolecular Sciences, Universiti Putra Malaysia (UPM), 43400 UPM \\ Serdang, Selangor, Malaysia \\ ${ }^{b}$ Laboratory of Biopolymer and Derivatives, Institute of Tropical Forestry and Forest Products (INTROP), Universiti Putra Malay sia, 43400, \\ UPM Serdang, Selangor, Malaysia
}

Received 6th July 2019 / Accepted 27th November 2019

\begin{abstract}
Organic and/or heavy metal pollutants in soil and wastewater can be remediated by phytoremediation. Phytoremediation combines the disciplines of plant physiology, soil microbiology and soil chemistry. There are several ways by which plants extract, stabilize, filtrate, volatilize or degrade the contaminants. However, the effectiveness of phytoremediation relies upon the type of plant used. Pennisetum purpureum, commonly referred to as Napier grass, is one of the exceptional phytoremediators due to its rapid growth rate and ability to survive in highly contaminated soils. In the present review, the potential use and applicability of $P$. purpureum to remediate various contaminated areas was highlighted and comprehensively discussed, especially the five phytoremediation mechanisms involved (i.e., phytodegradation, phytoextraction, phytofiltration, phytostabilization, phytovolatilization). The application and management of $P$. purpureum in soil and wastewater phytoremediation were also critically presented. The coupling of phytoremediation and bioenergy is the zero-waste concept that can be applied since $P$. purpureum contains high lignocellulosic content that can be utilized as carbon source for biofuel production, such as ethanol and butanol.
\end{abstract}

Keywords: Napier grass, phytodegradation, phytoextraction, phytofiltration, phytostabilization, phytovolatilization

\section{INTRODUCTION}

Most human activities including household, agriculture and industry produce large volumes of wastewater. In most cases, the wastewater goes untreated and is released directly to the environment. As water usage increases, so does the wastewater and as a consequence, the pollution load also increases. This in turn will negatively affect both human health and the ecosystem (WWP, 2017). However, the path towards solving this problem is a complex one; there are varying types of pollutants and pollution strengths of the wastewater, thus, an effective treatment system should take this into account. What is more, rapid urbanization and industrialization, as well as thriving agricultural activities, have also impacted on the soils integrity. Various hazardous and toxic pollutants from these activities will contaminate the soil. The recalcitrant nature of these pollutions is a serious threat to the environment and human health. Therefore, it comes as no surprise that the management of contaminated soil has become a great priority in developed and developing countries, which in turn, help support their

*Author for correspondence: Ahmad Muhaimin Roslan, Department of Bioprocess Technology, Faculty of Biotechnology and Biomolecular Sciences, Universiti Putra Malaysia (UPM), 43400 UPM Serdang, Selangor, Malaysia, Malaysia. Email - ar_muhaimin@upm.edu.my 
sustainable development (Enell et al., 2016). The effective handling of wastewater and soil pollution will benefit not only the environment and the ecosystem, but also improve the quality of human life. That is why it is imperative to devise a suitable method to overcome contaminated soil and wastewater issues, with low cost and good operational efficiency.

One of the suitable, sustainable and green approaches to treat wastewater and contaminated soil is through phytoremediation. In the past few years, phytoremediation has gained interest for the management of contaminated sites, including chemical or heavy metal contaminants. Phytoremediation has been defined by Truu et al. (2015) as "technology that is based on the combined action of plants and their associated microbial communities to degrade, remove, transform, or immobilize the toxic compounds present in soils, sediments, and more recently in polluted groundwater and wastewater in treatment wetlands". There are various types of contaminants that can be treated using phytoremediation, for instance pesticides, heavy metals, chlorinated solvents, petroleum hydrocarbons and radionuclides in soil and water. As compared to the conventional techniques of remediation, phytoremediation is low-cost, does not induce secondary contaminants, and presents low disruption towards the environment ( $\mathrm{Oh}$ et al., 2014; Truu et al., 2015). However, the effectiveness of the treatment wetlands for phytoremediation depends on the efficiency of the phytoremediator plant itself. Therefore, it is very important to select the most suitable plants to effectively treat the different types of wastewater.

One of the potential phytoremediator plants to be considered is Pennisetum purpureum. Pennisetum purpureum, also known as Cenchrus purpureus (synonym), Napier grass, Uganda grass or elephant grass, is a monocotyledonous flowering plant that belongs to the Poaceae family of grasses. This grass is a native plant to subtropical Africa, from which it is believed to have been distributed to other tropical and subtropical regions around the world (Negawo et al., 2017). There are a lot of $P$. purpureum cultivars. Over the last two decades, several $P$. purpureum cultivars have been introduced in Malaysia, for instance, King grass, Taiwan Napier, Red Napier and
Dwarf Napier (Halim et al., 2013). More importantly, $P$. purpureum is well known to be used as an animal feed, mainly in the cut and carry feeding systems, or made into hay or silage (Orodho, 2006). In addition, P. purpureum has also been used to produce biofuels because of its high cellulose content (Takara and Khanal, 2015). This high cellulose content can be utilized as a carbon source for the production of biofuels, such as ethanol and butanol (Ko et al., 2017; He et al., 2017). Furthermore, P. purpureum has also been used to scavenge pollutants, thus making this plant a suitable candidate in phytoremediation strategies.

\section{Pennisetum purpureum as a phytoremediator}

\subsection{Characteristics of Pennisetum purpureum as a phytoremediator}

A good phytoremediator species should have fast growth rates and high levels of biomass to accumulate large amounts of the contaminants in their systems. Fast-growing plants will make an exceptional phytoremediator due to their extensive root system, rapid growth and high water uptake (Couselo et al., 2012). Pennisetum purpureum, with its perennial nature, is well known as one of the fastest-growing plants in the world, and has high biomass yield (Karlsson and Vasil 1986; Cutts et al., 2011). Besides, according to Cutts et al. (2011), P. purpureum also has an efficient photosynthetic rate. This is accomplished by the unique spatial and physical properties of the bundle sheath cell wall of the plant which allows for minimal $\mathrm{CO}_{2}$ diffusion or leakage. As reported by Oliveira et al. (2014), P. purpureum generates up to 78 tons/ha of dry matter yield yearly, thus signifying its rapid growth.

Besides rapid growth, an ideal phytoremediator must also possess a high tolerance to the pollutants and the ability to degrade or concentrate high levels of pollutants in its biomass (Buhari et al., 2016). As reported by Ishii et al. (2015), P. purpureum can withstand several highly contaminated conditions. Liu et al. (2009) and Kang et al. (2012) also demonstrated that $P$. purpureum is resistant to media that are contaminated with heavy metals, including soil with a high copper level in a pot trial and in solutions containing stable caesium. This thus 
indicates that $P$. purpureum could be an ideal phytoremediator.

In addition, an ideal phytoremediator must also be tolerant to poor soil conditions. This is because, most of the contaminated soils are low in $\mathrm{pH}$, have high salinity, highly compact structure, and have very low or high water content (Lekić et al., 2017). In general, P. purpureum is an undemanding plant in terms of nutrient supply. It is capable of surviving on a broad range of soils; from poorly drained clay soils to excessively drained sandy soils, with the $\mathrm{pH}$ ranging from 4.5 to 8.2 (Rahman et al., 2008). Next, P. purpureum can also grow in the presence of contaminants like lead or chromium, without requiring mineral and nutrient supplements. Islam et al. (2017) demonstrated that there was no significant difference in the biomass yield of the $P$. purpureum when grown in the normal loamy soil or sandy soil even though the soil constituents (e.g., calcium, copper, phosphorus, magnesium, iron) were different. This further indicates that $P$. purpureum is robust enough to have similar growth rates either in polluted soil or in a normal, unpolluted one.

Moreover, a good phytoremediator should also be easy to handle and have a low maintenance cost (Lekić et al., 2017). P. purpureum is easy to grow, and it grows best in high and welldistributed rainfall areas where the annual rainfall is more than $1,000 \mathrm{~mm}$ (Orodho, 2006). Nevertheless, $P$. purpureum is also well adapted to drought conditions (Anderson et al., 2007). This is due to its deep root system which makes it possible to endure and stay alive during the drought (Kebede et al., 2016). So, the water requirement of $P$. purpureum is not an issue. In a nutshell, this versatile and durable plant makes an ideal choice as a phytoremediator in a treatment wetland system for managing wastewater and contaminated soil (which will be further discussed in later section).

\subsection{Types of phytoremediation}

Phytoremediation systems can be divided into several categories based on their mechanisms of removal (Figure 1) which are phytoextraction, phytofiltration (rhizofiltration), phytostabilization, phytovolatilization, and phytodegradation (Etim, 2012). Table 1 shows the phytoremediation processes involved when using $P$. purpureum as the phytoremediator.

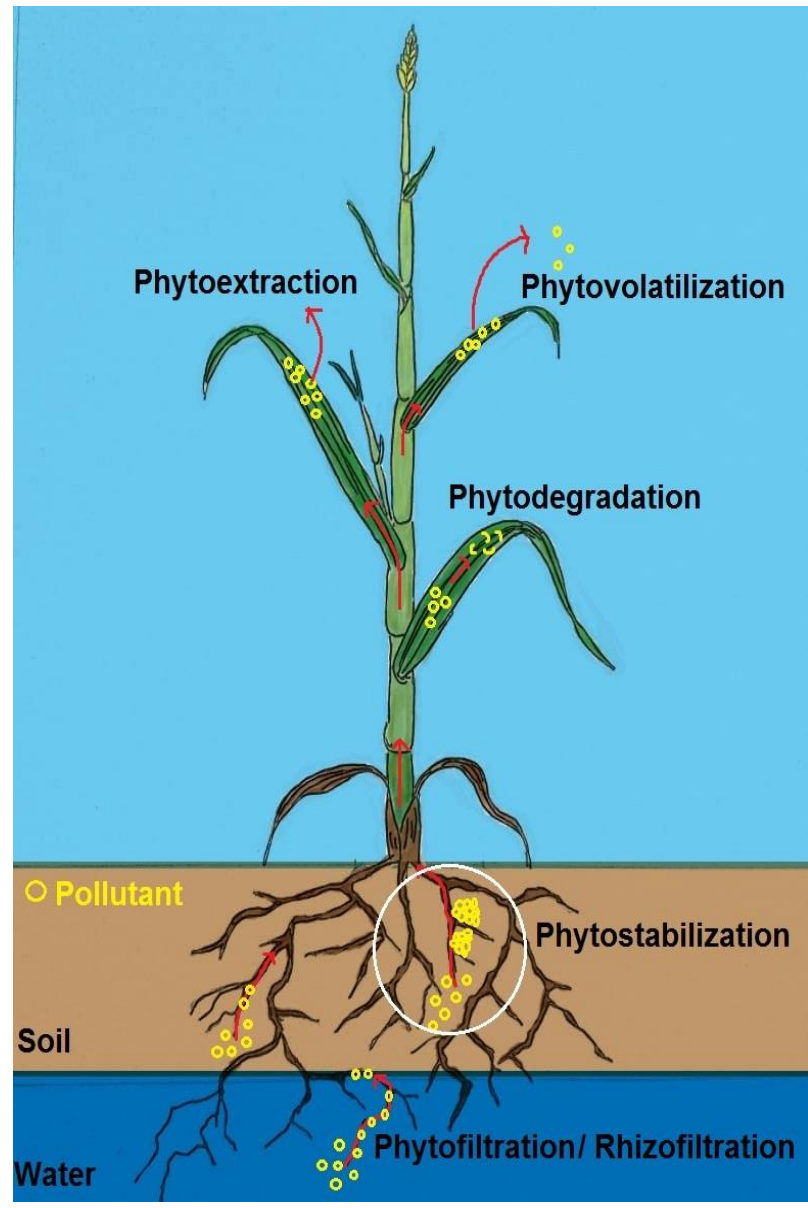

Figure 1. Potential phytoremediation strategies by $P$. purpureum. The pollutants in the soil or water can be immobilized (phytostabilization) and translocated into roots (phytofiltration/ rhizofiltration) through plasma membrane transporters. The pollutants can then be transported from the roots into the xylem and translocated into the shoots (phytoextraction). Phytovolatilization of the pollutants can be achieved through modification of these elements into volatile compounds. The degradation of organic pollutants into simple forms, which are considered non-polluting agents (phytodegradation) in the plant, can be achieved by enzymes (Dhankher et al., 2012; Mosa et al., 2016). 
Table 1. The processes involved in phytoremediation by $P$. purpureum as a phytoremediator.

\begin{tabular}{|c|c|c|c|c|c|}
\hline Process & Description & Type of waste & Contaminant & Final contaminant form & Reference \\
\hline \multirow{10}{*}{$\begin{array}{l}\text { Phytoextraction } \\
\text { (Hyper } \\
\text { accumulation) }\end{array}$} & \multirow{10}{*}{$\begin{array}{l}\text { Uptake of contaminants } \\
\text { into roots by } \\
\text { accumulation or } \\
\text { harvestable shoots }\end{array}$} & $\begin{array}{l}\text { Cd-contaminated } \\
\text { hydroponic solutions }\end{array}$ & Cadmium $(\mathrm{Cd})$ & \multirow[t]{10}{*}{$\begin{array}{l}\text { Phytochelatin (PC)-metal } \\
\text { complex* }\end{array}$} & Ishii et al. (2015) \\
\hline & & & Chromium (Cr), copper & & \\
\hline & & Tannery sludge & $\begin{array}{l}(\mathrm{Cu}), \mathrm{z} 1 \mathrm{nc}(\mathrm{Zn}) \text { and lead } \\
(\mathrm{Pb})\end{array}$ & & Juel et al. (2018) \\
\hline & & & Mercury (Hg) & & Abad et al. (2017) \\
\hline & & Mine tailing pond & Nickel (Ni) & & Singh (2003) \\
\hline & & Nickel chloride salt & Caesium (Cs) & & Kang et al. (2012) \\
\hline & & solution & Chromium (Cr), copper & & Ma et al. (2016) \\
\hline & & & $(\mathrm{Cu})$, manganese $(\mathrm{Mn})$ & & \\
\hline & & Hydroponic & zinc $(\mathrm{Zn})$, and lead $(\mathrm{Pb})$ & & \\
\hline & & Tailing waste & & & \\
\hline \multirow{2}{*}{$\begin{array}{l}\text { Phytovolatilization } \\
\text { (Volatilisation by } \\
\text { leaves) }\end{array}$} & \multirow[t]{2}{*}{$\begin{array}{l}\text { Volatilization of } \\
\text { contaminant by leaves }\end{array}$} & Crude oil & Hydrocarbon & \multirow{2}{*}{$\begin{array}{l}\text { Hydrocarbon gasses } \\
\text { Volatile DMDSe and } \\
\text { DMSe }\end{array}$} & $\begin{array}{l}\text { Ayotamuno et al. } \\
(2006)\end{array}$ \\
\hline & & $\begin{array}{l}\text { Se-laden saline } \\
\text { drainage sediment }\end{array}$ & Selenium (Se) & & $\begin{array}{l}\text { Kikuchi and Tanaka } \\
\text { (2012) }\end{array}$ \\
\hline \multirow{2}{*}{$\begin{array}{l}\text { Phytodegradation } \\
\text { (Degradation in } \\
\text { plant) }\end{array}$} & \multirow{2}{*}{$\begin{array}{l}\text { Microbial degradation in } \\
\text { the rhizosphere } \\
\text { stimulated by plants }\end{array}$} & Organic compound & POME final discharge & \multirow{2}{*}{$\begin{array}{l}\mathrm{CO}_{2}, \mathrm{H}_{2} \mathrm{O} \text {, inorganic } \\
\text { nutrient, simpler organic } \\
\text { compound }\end{array}$} & Ujang et al. (2018) \\
\hline & & Organic compound & Swine wastewater & & Klomjek et al. (2016) \\
\hline $\begin{array}{l}\text { Phytostabilization } \\
\text { (Complexation) }\end{array}$ & $\begin{array}{l}\text { Stabilization of } \\
\text { contaminant by } \\
\text { binding/complexation }\end{array}$ & Cadmium & $\begin{array}{l}\text { Cadmium }(\mathrm{Cd})- \\
\text { contaminated } \\
\text { hydroponic solutions }\end{array}$ & $\begin{array}{l}\text { Insoluble oxidation } \\
\text { state** }^{* *}\end{array}$ & $\begin{array}{l}\text { Wiangkham and } \\
\text { Prapagdee (2018) }\end{array}$ \\
\hline \multirow{2}{*}{$\begin{array}{l}\text { Phytofiltration } \\
\text { (Rhizosphere } \\
\text { accumulation) }\end{array}$} & \multirow[t]{2}{*}{$\begin{array}{l}\text { Removal of contaminant } \\
\text { by plant roots }\end{array}$} & Chlorobenzenes & Sewage sludge & \multirow[t]{2}{*}{ Metal cation** } & Alvarenga et al. (2017) \\
\hline & & Tannery sludge & $\begin{array}{l}\text { Chromium }(\mathrm{Cr}) \text {, copper } \\
(\mathrm{Cu}) \text {, zinc }(\mathrm{Zn}) \text { and lead } \\
(\mathrm{Pb})\end{array}$ & & Juel et al. (2018) \\
\hline
\end{tabular}




\subsubsection{Phytoextraction}

Phytoextraction, also referred to as phytoabsorption, phytoaccumulation or phytosequestration, is a process of contaminant uptake through the plant roots, preferably heavy metals from the contaminated soil and water (Razzaq, 2017). The contaminants then accumulate in the shoots or aerial parts of the plant. This process is then continued by harvesting the plant biomass to ensure the contaminants are safely disposed of, or removed from the remediated area (Mahar et al., 2016, Yadav et al., 2018).

Phytoextraction by fast-growing, high biomass-producing $P$. purpureum has been recognized as a promising approach for the remediation of water and soil pollution. This is because $P$. purpureum has the mechanism to tolerate high heavy metal concentrations accumulated in its shoots. For example, from the study by Ishii et al. (2015), the cadmium concentration in the soil was reduced by about $4.6 \%$ and $2.6 \%$ in a single year of $P$. purpureum cultivation with twice and once cutting, respectively. In addition, cadmiun concentration of $1.47 \mathrm{mg} / \mathrm{kg}$, which is almost equivalent to 15 $\mu \mathrm{M}$ cadmium, in the soil had no observable inhibition on the growth of P. purpureum (Ishii et al., 2015). The plant growth was as healthy as in cadmium-free soils which demonstrated that $P$. purpureum is a potential cadmium phytoextractor. Moreover, results from the study by $\mathrm{Ma}$ et al. (2016) also suggests that P. purpureum has good phytoextraction potential in removing other heavy metals such as lead, manganese, zinc, copper, and chromium from contaminated tailing wastes. Basically, tailing wastes, also known as mine dump is the waste rock or other material that overlies on mineral body and is displaced during mining without being processed. This waste is heavily polluted with heavy metals; which could pose serious threats to human health and productivity in agriculture (Chileshe et al., 2019).

There are several advantages of phytoextraction in remediating heavy metals in soil and wastewater. Firstly, the contaminants are permanently removed from the contaminated area. In some cases, the contaminants can also be recycled from the contaminated plant biomass (Etim, 2012), for example, recycling the metals from the biomass ash. Another benefit is the inexpensive cost of phytoextraction as compared to conventional methods (Etim, 2012), for example, electrochemical deposition, ion exchange, adsorption, flotation and chemical precipitation (Gunatilake, 2015). Besides being expensive, the conventional methods of extraction also have significant disadvantages associated with incomplete removal of the metal contaminants, large energy consumptions, and toxic sludge production, as compared to using phytoremediation plants such as $P$. purpureum (Eccles, 1999; Barakat, 2011). Even though phytoextraction is effective in removing heavy metal-polluted wastewater and soil, the disadvantage of this method is that the plant biomass must be harvested and disposed of properly in compliance with the set standards by the governing body (Raskin and Ensley, 2000).

\subsubsection{Phytovolatilization}

Similar to phytoextraction, phytovolatilization refers to a process where the contaminants, primarily organic compounds, are being absorbed into the plant body from contaminated soil or wastewater. However, unlike phytoextraction, phytovolatilization subsequently transforms and volatilizes the absorbed compounds into the atmosphere through its leaves by transpiration (Yadav et al., 2018), thus bypassing the need to harvest and dispose of the contaminated plant biomass as in phytoextraction. The absorption occurs as the plants absorb water and organic contaminants, with the contaminants being changed and reformed along the way as the water travels along the vascular system of the plants from the roots to the leaves. Then, the transformed compounds are volatilized into the air surrounding the plant (Akpor and Muchie, 2010). For example, volatile organic compounds, such as mercury and trichloroethylene may be volatized by either direct phytovolatilization which is volatilized from the stem and leaves in gaseous form, or by indirect phytovolatilization which is from the soil due to plant root activities (Limmer and Burken, 2016).

Phytovolatilization by $P$. purpureum involves the accumulation of the contaminants, the uptake of the heavy metals or organic compounds, and their subsequent conversion into gaseous species. This is achieved by partitioning of the absorbed 
contaminants into air spaces within the plant with a subsequent release into the atmosphere. According to Kikuchi and Tanaka (2012), besides its ability to accumulate selenium, $P$. purpureum has been discovered to have a specific metabolic selenium pathway, which means that selenium can be released as a volatile compound to the atmosphere. As explained by Gupta and Gupta (2017), the mechanism of selenium volatilization begins with the selenium present in soil being carried inside the plant through sulphate transporters that are present in the plasma membrane of root cells. It is then assimilated into organic selenium via the sulphur metabolic pathway inside the plant and volatilized as dimethylselenide (DMSe) and dimethyldiselenide (DMDSe) into the atmosphere. The volatilization of selenium in the form of DMSe and DMDSe may help prevent the toxicity inside the plant (Gupta and Gupta, 2017). Moreover, according to Pilon-Smits (2015), selenium released from plants has a negative effect on selenium-sensitive ecological partners, which may defend the plants from pathogens and herbivores. Conversely, it could cause allelopathic effects on the neighbouring plants. Besides selenium, the other compounds that can be volatilized by $P$. purpureum are petroleum hydrocarbons as stated by Ayotamuno et al. (2006). The results of the total hydrocarbon content from the study showed that phytoextraction and phytovolatilization could achieve the removal of petroleum hydrocarbons by approximately $83 \%$.

\subsubsection{Phytodegradation}

Most of the phytoremediation methods previously described primarily worked on removing heavy metals. It should be noted that contaminated soil and wastewater contain high amounts of organic pollutants as well. That is why phytodegradation or phytotransformation is an important mechanism performed by the phytoremediator plant. Phytodegradation is specifically for the removal of organic impurities because of the non-degradable properties of heavy metals (Yadav et al., 2018). Basically, this method involves the use of enzymes for the degradation of organic pollutants in plants. For example, the enzymes used are nitroreductase (conversion of explosives and other nitrated compounds), nitrilase (transformation of cyanated aromatic compounds), peroxidase (conversion of phenolic compounds), and dehalogenase (transformation of chlorinated compounds).

The phytodegradation ability of $P$. purpureum has been tested by Ujang et al. (2018) by determining the chemical oxygen demand (COD), ammonia degradation and colour removal of palm oil mill effluent (POME) final discharge using a constructed wetland system. The results obtained from this study showed that $P$. purpureum successfully reduced COD level by $71.57 \%$, ammonia by $85.97 \%$ and colour intensity by $87.62 \%$. Furthermore, this result is also supported by Klomjek et al. (2016) with 64\% and 70\% removal efficiency of biological oxygen demand (BOD) and total Kjeldahl nitrogen (TKN), respectively.

\subsubsection{Phytostabilization}

Phytostabilization, also referred to as phytoimmobilization, is the mechanism to reduce the bioavailability of pollutants, especially heavy metals in the environment by transforming the toxic compounds into non-toxic or less toxic forms and immobilizing them in the soil. For heavy metals present in a contaminated area, phytostabilization is not able to reduce their concentration, but instead, it prohibits their movement by accumulation through the roots, or precipitation within the rhizosphere in a similar manner to phytofiltration which operates under submerged conditions (Khalid et al., 2017).

$P$. purpureum can be regarded as a phytoremediator plant for cadmium phytostabilization. In the study by Wiangkham and Prapagdee (2018), it was stated that after six months of $P$. purpureum transplantation, cadmium concentrations in the roots were higher than in the shoots by 7.78 -fold. This may be due to the plant roots having a retention function of heavy metals, due to insolubilization or compartmentalization in cells, thereby avoiding their release to the xylem (Page and Feller, 2015). Thus, the heavy metals will be retained much more in the roots as compared to in the shoots. A longer retention time allows for more of the treatment processes to be completed. From this, it can be concluded that the plants that have 
a high cadmium content in the roots and low cadmium content in the shoots are suitable to be used for cadmium phytostabilization. It is also worth noting that the roots of $P$. purpureum have a strong ability to retain cadmium. In addition, the roots containing a stabilized form of cadmium can be harvested, and the cadmium can be recovered from the ash after the ashing process (Sahoo et al., 2016).

\subsubsection{Phytofiltration}

Phytofiltration is the method of phytoremediation that involves filtering and removing contaminants, mainly toxic substances, from wastewater. Limmer and Burken (2016) explained that phytofiltration functions by utilizing the plants' roots (rhizofiltration), seedlings (blastofiltration), or excised plant shoots (caulofiltration), to inhibit the organic pollutants from entering into streams or groundwater. Similar to phytoextraction, this method also involves the uptake of pollutants, especially heavy metals, from the roots and their accumulation in the plant biomass. This method also relies on the dense root system of the phytoremediator plant to slow down the flow of the wastewater just enough for sedimentation to occur. These movement reduction of the wastewater via a dense root mass is known as "hydraulic control". In conjunction, the slower speed of the water flow also gives ample time for the biota of the root system to react within the water. This results in the change of the surrounding $\mathrm{pH}$ because of the production of their metabolic product (Ratzke and Gore, 2018). The changes in $\mathrm{pH}$ then cause the precipitation of the heavy metals that will get trapped on the surfaces of the root of the plant (Ayangbenro and Babalola., 2017; Tangahu et al., 2011). Both the uptake and precipitation of contaminants allow for cleaner water to be filtered out of the wetland system. As stated by Yadav et al. (2018), the ideal plant for phytofiltration should comprise several traits. These include the ability to generate a considerable amount of root biomass that can grow under submerged conditions, the ability to accumulate and tolerate significant amounts of heavy metals, as well as ease of handling. Fortunately, P. purpureum meets all the required criteria as the ideal plant for phytofiltration as explained in subtopic 2.1 and 2.2.1.

P. purpureum has also been shown to be able to phytofiltrate contaminants like chlorobenzenes as stated by Alvarenga et al. (2017). Chlorobenzenes are aromatic organic compounds with low biodegradability and high toxicity (Nazari et al., 2019). Soil or wastewater contaminated by these compounds is of great environmental concern (Alvarenga et al., 2017). Chlorobenzenes are widely used in the production of electric transformers, lubricants, dyes and pesticides (Schroll et al., 2004), which result in their dispersion to the environment. This problem can potentially be solved by planting $P$. purpureum in the contaminated area. Alvarenga et al. (2017) showed that by cultivating $P$. purpureum in sewage sludge for 150 days, the concentrations of 1,4dichlorobenzene and 1,3,5-trichlorobenzene in sewage sludge decreased with a concomitant increase in the concentration in the roots along the cultivation period.

\section{Applications of Pennisetum purpureum}

The most common method in utilizing $P$. purpureum to remediate and manage wastewater and contaminated soil is by constructed wetlands. Constructed wetlands are an engineered system that has been designed to utilize the natural function of wetland vegetation, soil, and their microbial populations for the purpose of pollution control and waste management (Vymazal and Kröpfelová, 2008). The use of constructed wetlands for wastewater treatment has been increasing since the early 1980's (Carvalho et al., 2017). This is due to the capability of constructed wetlands to improve the quality of wastewater either from domestic, industrial or agricultural sources.

The major components of a constructed wetland mainly consist of a container that contains water, a substrate, and the phytoremediator plants (Figure 2). Other than this, the microbial and aquatic invertebrates' communities, which are the other important components of wetland, will develop naturally (Mahmood et al., 2013). The size of $P$. purpureum wetland system can be constructed either in a laboratory scale, pilot scale or large scale depending on their purpose and application. For 
instance, Ujang et al. (2018) designed a pilot scale size $\left(0.09 \mathrm{~m}^{3}\right)$ of horizontal flow constructed wetland for the treatment of palm oil mill effluent final discharge. The capacity of water loading for this design is about $5 \mathrm{~L}$ per day. In addition, for a large scale of wetland treatment system, the system can be constructed next to the wastewater effluent port as an in situ phytoremediation. The wastewater effluent can be channelled to the planted area undergoing the phytoremediation treatment, thus acting as an irrigation system.

Moving forward, one of the ideas to improve and upgrade this constructed wetland system is by constructing a mobile system. The constructed wetland system that consists of a container, substrates and phytoremediator plant can be set up on top of a vehicle as shown in Figure 3. The benefit of this mobile system is that it can become a support or back up system at the mill. In addition, it is also feasible for a bioremediation of spillage, where the mobile wetland system can easily be transported to the spill area and the spillage can be immediately remediated.

Other than constructed wetlands, hydroponic systems can also be applied to treat wastewater. Hydroponically grown P. purpureum has been reported to produce a large biomass and accumulate high concentrations of caesium in the aerial parts (Kang et al., 2012; Gupta and Walther, 2017). Besides, P. purpureum can also be applied in situ by directly transplanting it on the contaminated soil. For this method, the contaminated soil must be first ploughed before the transplantation of $P$. purpureum. The capability of this method was proven by a study of Ishii $e t a l$. (2015), where cadmium contaminated soil was successfully remediated with a reduction of $4.6 \%$.

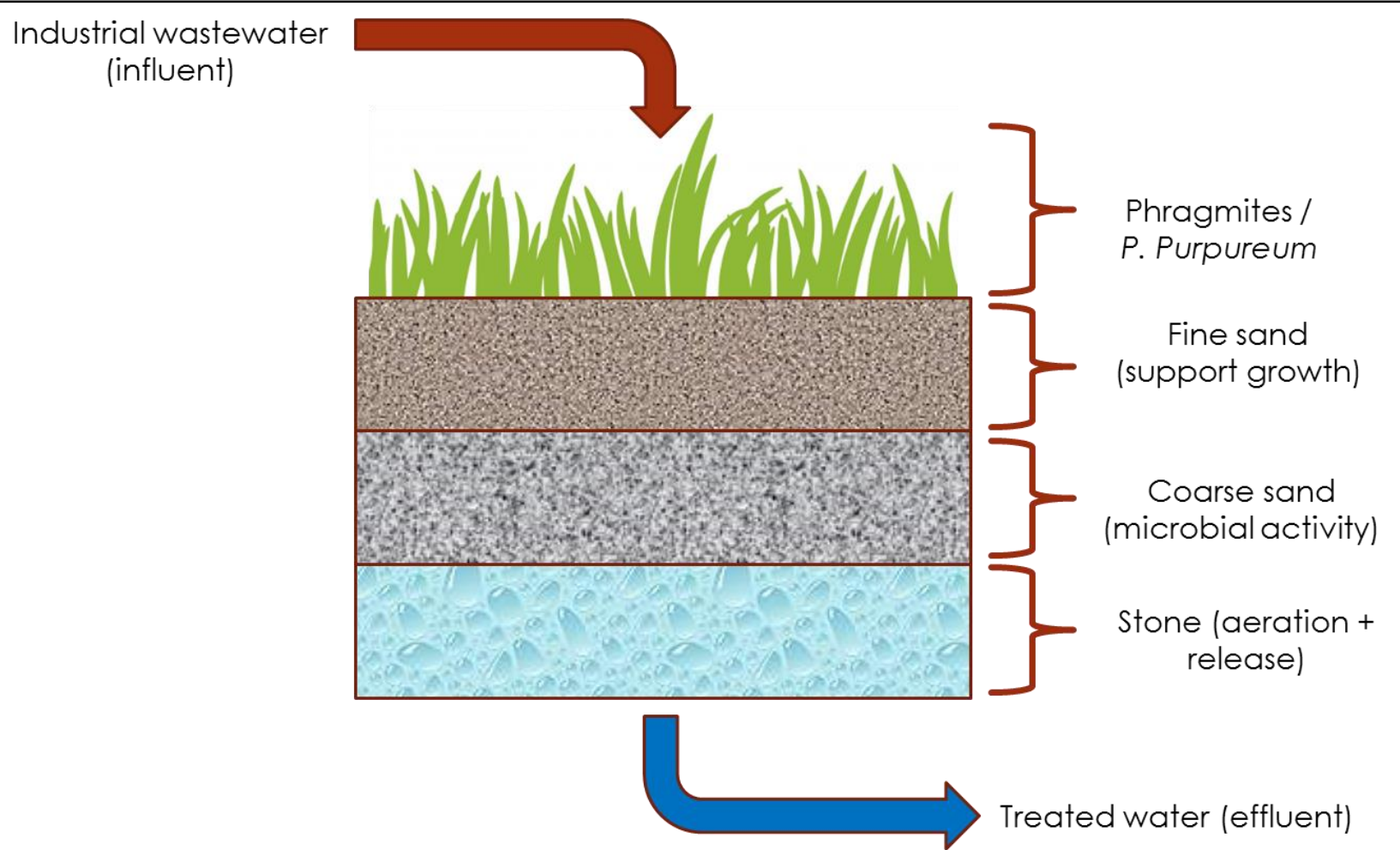

Figure 2. Constructed wetland design. 


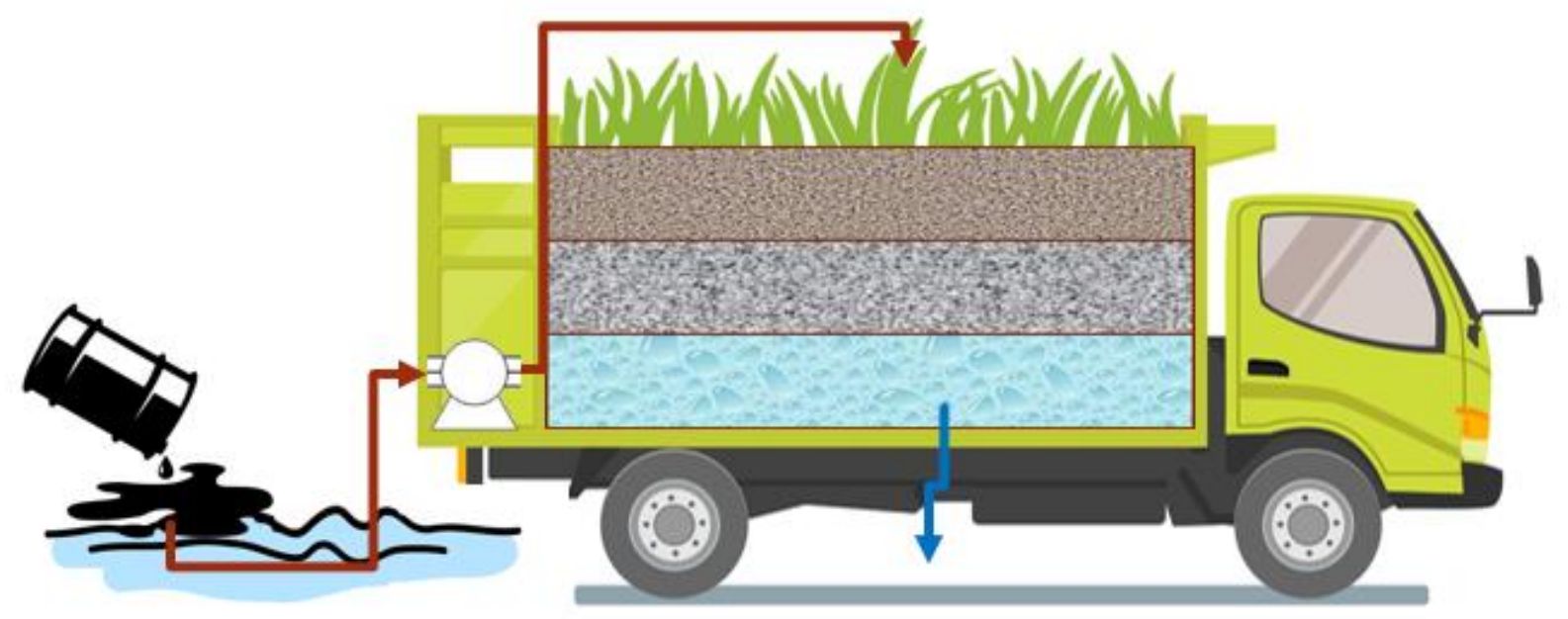

Figure 3. The new idea of mobile constructed wetland system. The polluted water can be pumped up from the polluted river, pond or any water system into the mobile constructed wetland through water pump (red arrow). The polluted water will then undergo phytoremediation and pass through the several layers of the constructed wetland. The clean water will then be discharged to the environment (blue arrow).

\section{Management of Pennisetum purpureum}

As previously discussed, $P$. purpureum has many qualities that make it an ideal phytoremediator: high biomass yield, fast growing rate, high tolerance to pollution, able to degrade contaminants, tolerant to poor soil conditions and having a low maintenance cost. However, this plant also has a few potential problems that might interfere in its role as a phytoremediator in a large scale phytoremediation.

One issue of $P$. purpureum is that it has been categorized as a potentially invasive species by the Florida Exotic Pest Plant Council and in the Global Compendium of Weeds (Randall, 2012). As reported by D'Antonio and Vitousek (1992), this grass is an aggressive invader with a fast growth rate which can easily colonize new areas and form dense growth. The problem arises when the invasion of this plant can change the structure and subsequently, the function of the natural ecosystem it invades (Gaertner et al., 2014). For example, it can alter the hydrology cycles, fire regimes, nutrient cycles, biophysical dynamics, and community composition of the ecosystem it invades (D'Antonio and Vitousek, 1992). The invasiveness of $P$. purpureum was described by López et al. (2014), where the grass that was initially introduced as forage for cattle in the United States became a weed in sugarcane plantings and invasive in natural areas over time.
Since the containment issue of this plant needs to be heavily considered, methods for controlling and managing this grass must be first set before utilizing it as a phytoremediator to remediate polluted area.

Chemical control, for example, the use of herbicides, is the most effective method for controlling invasive species. As mentioned by Grey et al. (2015), herbicides, for example, sethoxydim, glyphosate, or imazapyr can potentially eliminate $P$. purpureum populations from affected areas. The results from their study disclosed that applications of imazapyr and glyphosate reduced $P$. purpureum population by 74 and $94 \%$ respectively, and reduced the plant stem height by 6 and $15 \%$, respectively, as compared to the non-treated control. Although herbicides can be used to control this invasive grass, this routine will still pose potential negative impacts towards the environment due to the leaching of the herbicide components into the soil layer and underground water (El-Nahhal and Hamdona, 2017).

This invasive plant can also be controlled mechanically. This is achieved through physically removing the plant from the environment by cutting and pulling (Mattrick, 2006). These procedures do not require any special licensing or introduction of any chemicals into the environment. In addition, this method of cutting and pulling will result in high production of 
biomass, which can then be used as a source for bioenergy production.

\section{Phytoremediation Coupling to Bioenergy production}

Recently, the possible synergies between phytoremediation and bioenergy production have been increasingly investigated (Kumar et al., 2017). Phytoremediation will remove harmful contaminants and improve soil quality and at the same time renewable bioenergy such as biogas could be produced by utilizing the biomass harvested from the phytoremediation process (Hunce et al., 2019). This is due to the fact that the robust growth of $P$. purpureum during phytoremediation of contaminated soil and wastewater also indicates an increasing supply of fermentable sugars needed for the increased and continued bioenergy production. This integrated approach can lead to a more sustainable, ecofriendly, and economical alternative to conventional energy resources (Kumar et al., 2017). This is also one of the zero-waste concept management since all the biomass is being fully utilized (Figure 4).
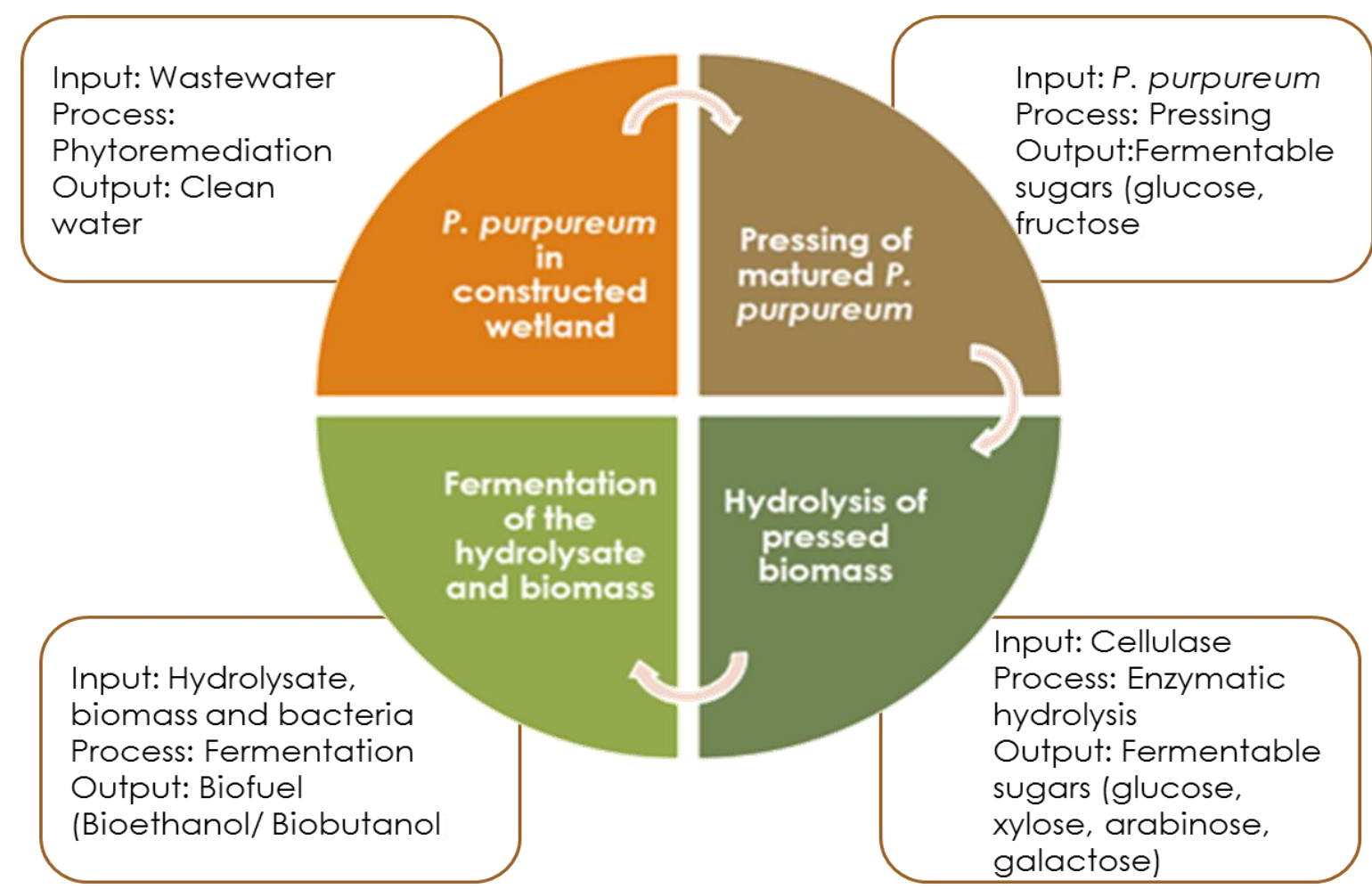

Figure 4. The Phytoremediation-Bioenergy Coupling Zero-Waste Concept.

In this context, the efficiency of $P$. purpureum for bioenergy production cannot be denied as it has been well studied that it can serve as a feedstock for biofuel processing (Mohammed et al., 2015; Mohammed et al., 2019; Takara and Khanal, 2015). As mentioned previously, P. purpureum is fast growing, has high biomass yield, and also has impressive adaptability to the environment which makes it a stable renewable source to produce biofuel (Wen et al., 2015). Besides, the structural analysis of $P$. purpureum shows that it has considerable cellulose, hemicellulose and lignin contents which are $40-50 \%, 20-40 \%$ and 10
$25 \%$ by weight respectively; which in turn indicate substantial sources of sugars for sustainable biofuel production (Mohammed et al., 2015; Takara and Khanal, 2015).

There are various studies conducted on the production of ethanol from P. purpureum. Yasuda et al. (2014) reported that by performing fermentation process using low-moisture anhydrous ammonia-treated $P$. purpureum, about $74.1 \%$ ethanol yield was achieved. In addition, from the finding of Bensah et al. (2015), $P$. purpureum exhibited the highest ethanol yield at $65.1 \%$ when compared with other biomass types 
studied (bamboo wood, rubber wood, Siam weed, and coconut husk). The ethanol yield's theoretical maximum is $35 \%$. This demonstrated that this plant offers a promising resource for biofuel production.

Moreover, the potential use of recovered $P$. purpureum contaminated with heavy metals for ethanol production has been investigated by Ko et al. (2017). The study showed that the zincpolluted biomass resulted in 10\% less efficient enzymatic hydrolysis of substrate when compared with the unpolluted biomass. On the other hand, cadmium polluted biomass resulted in 33\% less efficiency as compared to unpolluted biomass. Chromium showed similar results as cadmium. Furthermore, the fermentation efficiency of the heavy-metal-containing-biomass was also found to be higher than the control biomass. These findings thus conclude that ethanol production from biomass that was harvested after phytoremediation is feasible.

\section{CONCLUSION}

Even though rapid industrialization and urbanization signify major economic growth that boosts a country's gross domestic product, it also causes tremendous stress on the environment and the surrounding ecological system (Li et al., 2019). The production of wastewater and contaminated soil as the by-product of this economic development, if left untreated, will leave permanent adverse effects on the environment and its inhabitants (Wen et al., 2017). That is why phytoremediation technologies, which include phytostabilization, phytodegradation, phytovolatilization and phytoextraction, are the most promising strategies to remedy this problem. Using $P$. purpureum that is proven to be an efficient phytoremediator in a wetland system will make phytoremediation more sustainable and more practical in treating wastewater and soil pollution. In addition, $P$. purpureum which produces high biomass yield has also been used to produce bioenergy (Takara and Khanal, 2015). Hence, this phytoremediation approach could also benefit from the income generated through the production of bioenergy, both for its own maintenance as well as generating extra profit.
Thus, phytoremediation not only makes the environment cleaner, but also contributes to the growth of the economy; thereby providing a winwin solution for all. However, deeper research and pilot studies still need to be conducted to help improve and implement this phytoremediation technology together with bioenergy generation.

\section{ACKNOWLEDGEMENTS}

The authors would like to thank Universiti Putra Malaysia for the technical and financial assistance (Matching Grant No. 9560100) in the completion of the present review.

\section{REFERENCES}

Abad, I. M. G., Capundag Jr, R. O., Gamalo, J. C, Ascano II, C. P. \& Lacang, G. C. 2017. Phytoremediation potential of selected grass species in the Mine Tailing Pond of Sitio Manlauyan, Gango, Libona, Bukidnon, Philippines. Journal of Biodiversity and Environmental Sciences 11(5): 321-328.

Akpor, O. B. and Muchie, M. 2010. Remediation of heavy metals in drinking water and wastewater treatment systems: Processes and applications. International Journal of Physical Sciences 5(12):1807-1817.

Alvarenga, A. C., Sampaio, R. A., Pinho, G. P., Cardoso, P. H., Sousa, I. D. P. \& Barbosa, M. H. 2017. Phytoremediation of chlorobenzenes in sewage sludge cultivated with Pennisetum purpureum at different times. Revista Brasileira de Engenbaria Agricola e Ambiental 21(8), 573-578.

Anderson, W. F., Dien, B. S., Brandon, S. K. \& Peterson, J. D. 2007. Assessment of Bermuda grass and bunch grasses as feedstock for conversion to ethanol. Biotechnology for Fuels and Chemicals. ABAB Symposium (Part A: Enzyme Engineering and Biotechnology). Humana Press 2007:1321.

Ayangbenro, A., and Babalola, O. 2017. A New Strategy for Heavy Metal Polluted Environments: A Review of Microbial Biosorbents. International Journal of Environmental Research and Public Health 14(1):94.

Ayotamuno, J. M., Kogbara, R. B. \& Egwuenum, P. N. 2006. Comparison of corn and elephant grass in the phytoremediation of a petroleum-hydrocarboncontaminated agricultural soil in Port Harcourt, Nigeria. Journal of Food Agriculture and Environment $4(3 / 4): 218$.

Barakat, M. A. 2011. New trends in removing heavy metals from industrial wastewater. Arabian Journal of Chemistry 4(4):361377.

Bensah, E. C., Kádár, Z., \& Mensah, M. Y. 2015. Ethanol Production from Hydrothermally-Treated Biomass from West Africa. Bioresources 10(4):6522-6537.

Buhari, M. L., Sulaiman, B. R., Vyas, N. L., Sulaiman, B. \& Harisu, U. Y. 2016. Role of Biotechnology in Phytoremediation. Journal of Bioremediation \& Biodegradation 7: 330. 
Carvalho, P., Arias, C., \& Brix, H. 2017. Constructed Wetlands For Water Treatment: New Developments. Water 9:397.

Chileshe, M. N., Syampungani, S., Festin, E. S., Tigabu, M., Daneshvar, A., \& Odén, P. C. 2019. Physico-chemical characteristics and heavy metal concentrations of copper mine wastes in Zambia: implications for pollution risk and restoration. Journal of Forestry Research, P.1-11.

Couselo, J. L., Corredoira, E., Vieitez, A. M., \& Ballester, A. 2012. Plant Tissue Culture Of Fast-Growing Trees For Phytoremediation Research. In Plant Cell Culture Protocols. Humana Press, Totowa, Nj. 247-263.

Cutts, G. S., Webster, T. M., Grey, T. L., Vencill, W. K., Lee, R. D., Tubbs, R. S. \& Anderson, W. F. 2011. Herbicide effect on napier grass (Pennisetum purpureum) control. Weed science 59(2):255-262.

D'Antonio, C. M. and Vitousek, P. M. 1992. Biological invasions by exotic grasses, the grass/fire cycle, and global change. Annual review of ecology and systematics 23(1):63-87.

Dhankher, O. P., Pilon-Smits, E. A., Meagher, R. B. \& Doty, S. 2012. Biotechnological approaches for phytoremediation. Plant biotechnology and agriculture 309-328.

Eccles, H. 1999. Treatment of metal-contaminated wastes: why select a biological process? Trends in biotechnology 17(12):462465.

El-Nahhal, Y. and Hamdona, N. 2017. Adsorption, leaching and phytotoxicity of some herbicides as single and mixtures to some crops. Journal of the Association of Arab Universities for Basic and Applied Sciences 22(1): 17-25.

Enell, A., Andersson, Y., Vestin, J. \& Wagelmans, M. 2016. Risk management and regeneration of brownfields using bioenergy crops. Journal of Soils and Sediments 16(3):9871000.

Etim, E. E. 2012. Phytoremediation and its mechanisms: a review. International Journal of Environment and Bioenergy 2(3):120-136.

Gaertner, M., Biggs, R., Te Beest, M., Hui, C., Molofsky, J., \& Richardson, D. M. 2014. Invasive Plants as Drivers of Regime Shifts: Identifying High-Priority Invaders That Alter Feedback Relationships. Diversity and Distributions 20(7):733-744.

Grey, T. L., Webster, T. M., Li, X., Anderson, W. \& Cutts, G. S. 2015. Evaluation of control of Nnapier grass (Pennisetum purpureum) with tillage and herbicides. Invasive Plant Science and Management 8(4):393-400.

Gunatilake, S. K. 2015. Methods of removing heavy metals from industrial wastewater. Journal of Multidisciplinary Engineering Science Studies 1(1):12-18.

Gupta, D. K., and Walther, C. 2017. Impact of Cesium on Plants and the Environment. Springer International Publishing. P. 113.

Gupta, M. and Gupta, S. 2017. An overview of selenium uptake, metabolism, and toxicity in plants. Frontiers in plant science 7: 2074.

Halim, R. A., Shampazuraini, S. \& Idris, A. B. 2013. Yield and nutritive quality of nine Napier grass varieties in Malaysia. Malaysian Journal of Animal Science 16(2): 37-44.

Hanna, W. W., Chaparro, C. J., Mathews, B. W., Burn, J. C., Sollenberger, L. E. \& Carpenter, J. R. 2004. Perennial Pennisetums. In: Moser LE, Burson BL, Sollenberger LE (Eds.), Warm-Season (C4) Grasses. ASA-CSSA-SSSA, Madison, WI. 2004:503-535.

He, C. R., Kuo, Y. Y. \& Li, S. Y. 2017. Lignocellulosic butanol production from Napier grass using semi-simultaneous saccharification fermentation. Bioresource Technology 231:101108.

Hunce, S. Y., Clemente, R., \& Bernal, M. P. 2019. Energy Production Potential of Phytoremediation Plant Biomass:
Helianthus Annuus and Silybum Marianum. Industrial Crops and Products 135:206-216.

Ishii, Y., Hamano, K., Kang, D. J., Idota, S. \& Nishiwaki, A. 2015. Cadmium phytoremediation potential of napier grass cultivated in Kyushu, Japan. Applied and Environmental Soil Science 2015.

Islam, M. S., Sarker, N. R., Habib, M. A., Ali, M. Y. \& Yeasmin, T. 2017. Effect of different soil types on growth and production of Napier-4 at the Regional Station of BLRI. Asian Journal of Medical and Biological Research 3(2): 182185.

Juel, M. A. I., Dey, T. K., Akash, M. I. S. \& Kumar, K. 2018. Heavy Metals Phytoremediation Potential Of Napier Grass Cultivated In Tannery Sludge. $4^{\text {th }}$ International Conference on Civil Engineering for Sustainable Development (ICCESD 2018).

Kang, D. J., Seo, Y. J., Saito, T., Suzuki, H. \& Ishii, Y. 2012. Uptake and translocation of cesium-133 in napier grass (Pennisetum purpureum Schum.) under hydroponic conditions. Ecotoxicology and environmental safety 82: 122-126.

Karlsson, S. B. and Vasil, I. K. 1986. Growth, Cytology and Flow Cytometry of Embryogenic Cell Suspension Cultures of Panicum maximum Jacq. and Pennisetum purpureum Schum. Journal of plant physiology 123(3): 211-227.

Kebede, G., Feyissa, F., Assefa, G., Mengistu, A., Minta, M., \& Tsadik, T. 2016. Agronomic Performance and Nutritive Values of Napier Grass (Pennisetum Purpureum (L.) Schumach) Accessions in the Central Highland of Ethiopia. International Journal of Development Research 06:8717-8726.

Khalid, S., Shahid, M., Niazi, N. K., Murtaza, B., Bibi, I. \& Dumat, C. 2017. A comparison of technologies for remediation of heavy metal contaminated soils. Journal of Geochemical Exploration 182:247-268.

Kikuchi, T. and Tanaka, S. 2012. Biological removal and recovery of toxic heavy metals in water environment. Critical Reviews in Environmental Science and Technology 42(10):1007-1057.

Klomjek, P. 2016. Swine wastewater treatment using vertical subsurface flow constructed wetland planted with Napier grass. Sustainable Environment Research 26:217-23.

Ko, C. H., Yu, F. C., Chang, F. C., Yang, B. Y., Chen, W. H., Hwang, W. S. \& Tu, T. C. 2017. Bioethanol production from recovered napier grass with heavy metals. Journal of Environmental Management 203:1005-1010.

Kumar, S., Singh, R., Kumar, V., Rani, A., \& Jain, R. 2017. Cannabis Sativa: A Plant Suitable for Phytoremediation and Bioenergy Production. In Phytoremediation Potential of Bioenergy Plants P. 269-285.

Lekić, M., Crnogorac, L., Pantelic, U. \& Nikić, Z. 2017. Possibility of application of phytoremediation in mining. 6th International symposium, mining and environmental protection,21-24 June 2017. Vrdnik, Serbia. 2017: 355-360.

Li, M., Li, L., \& Strielkowski, W. 2019. The Impact of Urbanization and Industrialization on Energy Security: A Case Study of China. Energies 12(11):2194.

Limmer, M. and Burken, J. 2016. Phytovolatilisation of organic contaminants. Environmental Science Technology 50:6632-6643.

Liu, X., Shen, Y., Lou, L., Ding, C. \& Cai, Q. 2009. Copper tolerance of the biomass crops Elephant grass (Pennisetum purpureum Schumach), Vetiver grass (Vetiveria zizanioides) and the upland reed (Phragmites australis) in soil culture. Biotechnology Advances 27(5):633-640.

López, Y., Seib, J., Woodard, K., Chamusco, K., Sollenberger, L., Gallo, M., Flory, S.L. \& Chase, C. 2014. Genetic diversity of biofuel and naturalized napiergrass (Pennisetum purpureum). Invasive Plant Science and Management 7(2):229-236.

Ma, C., Ming, H., Lin, C., Naidu, R. \& Bolan, N. 2016. Phytoextraction of heavy metal from tailing waste using Napier grass. Catena 136: 74-83. 
Mahar, A., Wang, P., Ali, A., Awasth, M. K., Lahori, A. H., Wang, Q., Li, R. \& Zhan, Z. 2016. Challenges and opportunities in the phytoremediation of heavy metals contaminated soils: a review. Ecotoxicology and environmental safety 12: 111-121.

Mahmood, Q., Pervez, A., Zeb, B. S., Zaffar, H., Yaqoob, H., Waseem, M., and Afsheen, S. 2013. Natural Treatment Systems as Sustainable Ecotechnologies for the Developing Countries. Biomed Research International vol. 2013.

Mattrick, C. 2006. Managing Invasive Plants, Methods of Control. Conservation Notes from the New England Wild Flower Society 2006:20-23.

Mohammed, I. Y., Abakr, Y. A., \& Mokaya, R. 2019. Biofuel and Valuable Products Recovery from Napier Grass PreProcessing: Process Design and Economic Analysis. Journal of Environmental Chemical Engineering 7(2):102962.

Mohammed, I. Y., Abakr, Y. A., Kazi, F. K., Yusup, S., Alshareef, I. \& Chin, S. A. 2015. Comprehensive characterization of napier grass as a feedstock for thermochemical conversion. Energies 8(5): 3403-3417.

Mosa, K. A., Saadoun, I., Kumar, K., Helmy, M. \& Dhankher, O.P. 2016. Potential biotechnological strategies for the cleanup of heavy metals and metalloids. Frontiers in plant science 7:303.

Nazari, R., Rajić, L., Ciblak, A., Hernández, S., Mousa, I. E., Zhou, W., Bhattacharyya, D., \& Alshawabkeh, A. N. 2019. Immobilized Palladium-Catalyzed Electro-Fenton's Degradation of Chlorobenzene in Groundwater. Chemosphere 216:556-563.

Negawo, A. T., Teshome, A., Kumar, A., Hanson, J \& Jones, C. S. 2017. Opportunities for Napier grass (Pennisetum purpureum) improvement using molecular genetics. Agronomy 7(2):28.

Oh, K., Cao, T., Li, T. \& Cheng, H. 2014. Study on application of phytoremediation technology in management and remediation of contaminated soils. Journal of Clean Energy Technologies 2(3):216-220.

Oliveira, M. L. F., Daher, R. E. F., de Amara Gravina, G., da Silva, V. B., Rodrigues, E. V. O., Shimoya, A., do Amaral Junior, A. T., da Silva Menezes, B. R. \& dos Santos Rocha, A. 2014. Pre-breeding of elephant grass for energy purposes and biomass analysis in Campos dos Goytacazes-RJ, Brazil. African Journal of Agricultural Research 9(36):27432758.

Orodho, A. B. 2006. The role and importance of Napier grass in the smallholder dairy industry in Kenya. Food and Agriculture Organization, Rome, Italy.

Page, V., and Feller, U. 2015. Heavy Metals in Crop Plants: Transport and Redistribution Processes on the Whole Plant Level. Agronomy 5(3):447-463.

Pilon-Smits, E. A. 2015. Selenium in plants. In Progress in botany 2015: 93-107.

Rahman, M. M., Ishii, Y., Niimi, M. \& Kawamura, O. 2008. Effect of salinity stress on dry matter yield and oxalate content in napiergrass (Pennisetum purpureum Schumach). AsianAustralasian Journal of Animal Sciences 21(11): 1599-1603.

Randall, R. P. 2012. A Global Compendium of Weeds. Perth, Australia: Department of Agriculture and Food Western Australia 2012:1124.

Raskin, I. and Ensley, B.D. 2000. Recent developments for in situ treatment of metal contaminated soils. In: Phytoremediation of Toxic Metals: Using Plants to Clean Up the Environment. John Wiley \& Sons Inc., New York.

Ratzke, C., and Gore, J. 2018. Modifying and Reacting To the Environmental $\mathrm{pH}$ Can Drive Bacterial Interactions. Plos Biology 16(3):E2004248.

Razzaq, R. 2017. Phytoremediation: An environmental friendly technique-A review. Journal of Environmental Analytical Chemistry 4(2):195.

Sahoo, P. K., Kim, K., Powell, M. A. \& Equeenuddin, S. M. 2016. Recovery of metals and other beneficial products from coal fly ash: A sustainable approach for fly ash management. International Journal of Coal Science \& Technology 3(3):267-283.

Schroll, R., Brahushi, F., Dörfler, U., Kühn, S., Fekete, J. \& Munch, J. C. 2004. Biomineralisation of 1,2,4-trichlorobenzene in soils by an adapted microbial population. Environmental Pollution 127:395-401.

Singh, M. V. 2003. Bioaccumulation and Tolerance of Nickel In Selected Plant Species. In Wastewater Treatment and Waste Management: Proceedings of the International Conference on Water and Environment (WE-2003) Bhopal, India 4:14.

Takara, D. and Khanal, S. K. 2015. Characterizing Compositional Changes of Napier Grass at Different Stages of Growth for Biofuel and Biobased Products Potential. Bioresource Technology 188:103-108.

Tangahu, B. V., Abdullah, S., Rozaimah, S., Basri, H., Idris, M., Anuar, N., \& Mukhlisin, M. 2011. A Review on Heavy Metals (As, $\mathrm{Pb}$, And $\mathrm{Hg}$ ) Uptake by Plants through Phytoremediation. International Journal of Chemical Engineering.

Truu, J., Truu, M., Espenberg, M., Nõlvak, H. \& Juhanson, J. 2015. Phytoremediation and plant-assisted bioremediation in soil and treatment wetlands: a review. The Open Biotechnology Journal 9:85-92.

U. S. Environmental Protection Agency (EPA), "Introduction to Phytoremediation," National Risk Management Research Laboratory, EPA/600/R-99/107, 2000.

Ujang, F. A., Osman, N. A., Idris, J., Halmi, M. I. E., Hassan, M. A. \& Roslan, A. M. 2018. Start-up treatment of palm oil mill effluent (POME) final discharge using Napier Grass in wetland system. In IOP Conference Series: Materials Science and Engineering 368(1):012008

Vymazal, J., and Kröpfelová, L. 2008. Wastewater Treatment in Constructed Wetlands with Horizontal Sub-Surface Flow (Vol. 14). Springer Science \& Business Media. P 4-5.

Wen, B., Yuan, X., Li, Q. X., Liu, J., Ren, J., Wang, X. \& Cui, Z. 2015. Comparison and evaluation of concurrent saccharification and anaerobic digestion of Napier grass after pretreatment by three microbial consortia. Bioresource technology 17:102-111.

Wen, Y., Schoups, G., \& Van De Giesen, N. 2017. Organic Pollution of Rivers: Combined Threats of Urbanization, Livestock Farming and Global Climate Change. Scientific Reports 7:43289.

Wiangkham, N. and Prapagdee, B. 2018. Potential of Napier grass with cadmium-resistant bacterial inoculation on cadmium phytoremediation and its possibility to use as biomass fuel. Chemosphere 201:511-518.

World Water Assessment Program (UNESCO WWAP). 2017. The United Nations World Water Development Report 2017. Wastewater: The Untapped Resource.

Yadav, K. K., Gupta, N., Kumar, A., Reece, L. M., Singh, N., Rezania, S. \& Khan, S.A. 2018. Mechanistic understanding and holistic approach of phytoremediation: A review on application and future prospects. Ecological Engineering 120: 274-298.

Yadav, S. K. 2010. Heavy metals toxicity in plants: an overview on the role of glutathione and phytochelatins in heavy metal stress tolerance of plants. South African Journal of Botany 76(2):167-179.

Yasuda, M., Ishii, Y. \& Ohta, K. 2014. Napier Grass (Pennisetum Purpureum Schumach) As Raw Material Forfor Bioethanol Production: Pretreatment, Saccharification, Andand Fermentation. Biotechnology And Bioprocess Engineering 19(6):943-950. 